\title{
Working toward Global Justice: Confucian and Christian Ethics in Dialogue
}

\section{Andreas Rauhut ${ }^{1}$}

Published online: 24 January 2020

(C) The Author(s) 2020

\begin{abstract}
Faced with the ongoing tragedy of poverty in our world today, many have long called for a common standard of global justice. Such a standard should not be tied to any one particular strand of justice conceptualizations and it should yet be in harmony with the central motivating beliefs of the various concerned moral worldviews. The article reframes global justice thinking by approaching a core problem, namely motivating people to care for distant needy strangers, in a concrete intercultural manner: it sets out to study and compare the motivational underpinnings for an expansion of social justice, in an exemplary fashion, within two long-standing worldview traditions, namely Christian social ethics and contemporary Confucian ethics, in order to gain a more realistic impression of what a commonly shared and motivationally backed notion of global justice may look like. While the former expresses a universal concern for the poor, the latter has recently attracted interest, since Southeast Asian countries managed to lift millions of people out of abject poverty. As both traditions consider loving communal relationships to constitute the foundation of all justice considerations, the article inquires how this quest shapes each tradition's way to motivate their adherents' compliance with a vision of global justice.
\end{abstract}

Keywords Motivation - Global justice - Christian social ethics · Confucian ethics · Poverty · Intercultural dialogue

\section{Introduction}

The practical urgency to fight poverty looms large in today's world. More than 800,000 human beings still live and die in absolute poverty, even though there are more than enough resources on our planet to feed all of us (United Nations 2015: 8). ${ }^{1}$ While in

\footnotetext{
${ }^{1}$ The report describes the millennium development goals' initial key objective to reduce so-called extreme poverty by $50 \%$ as attained, yet it had to push its baseline of comparison back to 1990 to be able to say so. While 1.9 billion suffered from extreme poverty in 1990, in 2015 there were still 836 million.
}

Andreas Rauhut

AJRauhut@aol.com

1 Theologisches Studienzentrum Berlin, Evangelische Hochschule Tabor, Marburg, Lehrter Straße 68, 10557 Berlin, Germany 
recent decades the number of the "extreme poor" decreased, the situation remains alarming: each day more than 15,000 children under five die, mostly from preventable causes (United Nations 2015: 8). Most of the dynamics that cause poverty to persist are still in place. ${ }^{2}$

This tragedy is nothing new of course, and it has been the subject of intense research and heated debates in social and political sciences for decades, resulting in the formation of different schools of thought. The conceptualization of what causes poverty as well as the proposed measures to fight poverty differ vastly between these schools: many, especially in the West, seek to tackle poverty within the conceptual framework of a liberal political and economic world order. They advocate a global market economy backed by liberal democratic nation states that guarantee free trade and institutional stability, which is presumed to be the result of rule of law and a human rights ethic defending individual liberties. Others, often in non-Western countries, point to the fact that these principles do not qualify as a universalizable framework for prosperity (de Soto 2001, Naim 2000, Hoogvelt 2001). They argue that the very imposition of these principles to non-Western countries has often produced the opposite effect, namely a "descent into social decay and economic stagnation" (W. Chen 2014: 4). ${ }^{3}$ Pointing to the remarkable development of the high performing East Asian countries such as the P. R. of China, which has lifted hundreds of millions of people over the threshold of absolute poverty within just a few years, they uphold that developing nations are better off not following the "Washington Consensus," but should rather pursue "illiberal or de-Western strategies of development" that better fit their own mode of national integration (W. Chen 2014: 6). From a social and political science point of view, the routes to modernity then may well differ for different countries (Berger 1988: 4-7).

From an ethical point of view, the tragedy of people dying from poverty is so great, however, that merely comparing various development paths seems to be not enough. In the last decades the concern to fight poverty globally and the call for concerted efforts to do so has spurned a common quest for global justice. Interestingly enough, the push to find a common understanding of global justice has not been totally usurped by any one of the aforementioned schools of thought, but has rather functioned as a shared forum for discussion. This is all the more noteworthy since the expression "global justice" seems to imply an inherent affinity to the primacy of justice over against the competing claim of a primacy of the "good life," that is, a normative conceptual affinity to the liberal Western, individual-focused recipe of social construction putting the autonomous, unsituated moral self at the center of its attention. While there certainly is a "universalistic trend of global justice ethics [...] that goes closely hand in hand with [moral] cosmopolitanism" (Hellsten 2015: 86) led by scholars like Thomas Pogge or Charles Beitz (Pogge 2010, Beitz 1983), the global justice debate as a whole has also

\footnotetext{
2 "Gender inequality persists. Big gaps exist between the poorest and richest and between rural and urban areas. Climate change and environmental degradation undermines progress achieved, and poor people suffer most. Armed conflicts remain the biggest threat to human development" (United Nations 2015: 8).

${ }^{3}$ CHEN Weigang rephrases Hoogvelt (Hoogvelt 2001: 175). Following Samir Amin (Amin 1974: 9), Chen termed this the paradox of "peripheral liberal deformation." The institutional recipe that sparked growth, prosperity, and stability within the Western core countries cannot be successfully copied in countries of the peripheral world. Apparently the preconditions between these countries with regard to their culturally formed ethics differ markedly. Compare with Chen, who devotes his study affirming the Weberian paradox to discovering how non-Western nations can combine a spirit of civic political stability and a universalistic understanding of social justice on their own cultural terms (see W. Chen 2014: 4-10).
} 
been enriched by viable contributions from very different ideological perspectives, such as that of communitarians like Alasdair MacIntyre and Michael Walzer, from NeoAristotelians like Martha Nussbaum, as well as from staunch proponents of nationalism such as David Miller or particularism like FAN Ruiping and Daniel A. Bell (MacIntyre 1984, Walzer 1983, Nussbaum 2007, Miller 2007, Fan 2010, D. A. Bell 2006). Moreover, it is noteworthy that some of the earliest (Oruka 1981, 1988) as well as the currently most comprehensive contributions discussing global justice (Okeja 2013, W. Chen 2014) were made by scholars born in non-Western countries. ${ }^{4}$ Finally, note that John Rawls, the godfather of modern-day Western justice debates in political science and political philosophy, holds that his very own renowned "justice as fairness" account is applicable only to traditionally liberal societies (Rawls 1996: 6-15). Opting for a contextualist metaperspective, Rawls proposed an international conception of justice that can be accepted by both liberal peoples and what he terms "decent hierarchical peoples" (Rawls 2001: 75). In sum, then, it can be said that the quest for global justice is not intrinsically bound to any one strand of justice conceptualization.

This article supports and intensifies the quest for global justice by reframing its problems in a concrete intercultural manner, thus applying the insights of intercultural communication and philosophy to the global justice debate. It stages a concrete dialogue between two longstanding worldview-grounded traditions of moral orientation in exemplary manner. In so doing it complements the existing abstract philosophical work about global justice as well as the existing accounts of any one particular tradition's take on global justice.

The dialogical approach to global justice that this article proposes will provide helpful new insights for the global justice debate at large. This claim rests on three central premises. First, the core convictions of democratic reasoning require that discussions addressing moral problems concerning people from different cultural backgrounds should be framed in a mode that reflects the cultural differences from the very beginning, giving a voice to each party concerned. ${ }^{5}$ Second, sharing the basic optimism that members of different traditions or cultures can converse with each other in a mutually commensurable manner, I am also optimistic about the possibility that inter- or cross-cultural critique can help one become aware of blind spots in one's own tradition that need further scrutiny and possibly complementation (following Sen 2010: 45; Metz and D. A. Bell 2012; Benhabib 2013: 6; Wiredu 1996: 20). Finally, and possibly most importantly, pushing the norm discourse closer to each tradition's actual homeland increases the potential to come up with shared understandings of justice that go hand in hand with contextually accepted moral values and beliefs, which will help to ensure the willful consent and heartfelt acceptance of these norms by all affected people.

\footnotetext{
${ }^{4}$ These contributions clearly exceed and even contrast the core notions of classic Western social justice conceptualizations that seek to provide "a notion of the primacy of social justice that transcends the limits of liberal democracy" (W. Chen 2014: 17).

${ }^{5}$ This argument is inspired and supported by (a) the growing body of praxis-oriented scholarship in both intercultural philosophy and comparative religious ethics, (b) the assumption of the possibility of a "nonevaluation oriented mode of hermeneutical understanding" (Benhabib 1986: 309), as well as (c) the conception of intercultural discourse ethics as a discourse on two different levels, the way Delanty suggests (Delanty 1997). Delanty describes how dialogue on the first level establishes deep, nonevaluative mutual understandings within the parameters of the discourse partner's worldview, which pave the way for the second deliberative level, where the debating parties seek to find creative solutions to concrete moral problems.
} 
As space is limited, I outline the envisioned dialogue merely as an example by portraying two time-tested traditions of moral reflection in dialogue with each other. In doing so I narrow down the sources for each portrayal to a few, contemporary, widely received documents or authors within each tradition, thereby foregoing each tradition's myriad different historical manifestations.

I here choose to focus on a dialogue between Christian social ethics (CSE) and Confucian ethics (CE). It appears intriguing to posit two moral traditions on a level plane, which have reliably provided moral orientation to many people, yet differ markedly in their scope of application and their mechanism of motivation.

Opting for Christian social ethics as a first dialogue partner reflects my background as a Christian ethicist. It also accounts for what has been recognized as the particular strengths of CSE, namely providing a solid groundwork for universal human dignity considerations, being a religious tradition that highlights and demands universal concern for the poor (Walzer 2010: 291; Cahill 2013: 30). Within the plurality of Christian ethical voices I will focus on the Roman Catholic tradition's ethical reflection of poverty, justice, and global affairs.

Selecting Confucian ethics as the other dialogue partner is the logical consequence of taking into account other non-Western paths to modernity and taking into serious consideration their well-reasoned reservations over against cosmopolitan accounts of establishing universal justice by extending the institutions of a liberal democratic order of Western nation states to the world governance level (W. Chen 2014: 15). As societies that respect Confucian values have chosen distinctively successful pathways to economic prosperity and as - especially in the context of poverty alleviation-what came to be termed the "China model" has attracted economists" attention (Ravallion and S. Chen 2007; So 2012: 1; Rawski 2011: 334; Hu 2007: 41; Fan 2010: 238), apparently the so-called "post-Confucianist hypothesis" that has been discussed since about 30 years ago is all the more valid, leading us to choose contemporary interpretations of Confucian moral norm reflection as the second dialogue partner.

I first delineate the central moral values and ethical arguments regarding poverty and justice in each of the two traditions. I will then proceed to compare and contrast their respective stances by pointing out similarities and discussing differences. In closing I will delineate a body of shared and complementary elements, which may be regarded as building blocks for a more deeply motivationally saturated account of global justice.

\section{Poverty and Justice in a Confucian Ethical Understanding}

Before turning to particular beliefs and arguments about social justice and its scope, a few remarks about the origins and fundamental moral beliefs salient in CE seem necessary.

Emerging in turbulent times of transition between the 5th and 3rd century B.C.E., the teachings of Confucius, Mencius, and Xunzi 荺子, the founding fathers of what later came to be known in the West as Confucianism, reframed ancient Chinese beliefs about morality and political stability. The early Confucians sought to integrate all human interactions into an order of “dynamic harmony" (Li 2008: 427). Such harmony (he 和) does not simply result from government enforcing the rule of law, nor is it a matter of letting all things have their own way (Li 2014: 117-147). It rather emerges when 
people develop their character in accordance with the virtues of ren 仁, namely "love, care or respect for others" (Wong 2013). People acquire this other-regarding attitude and disposition to act by participating in communal rituals ( $l i$ 禮) in their families (Bai 2012: 32; Neville 2008: 95). The family provides the paradigmatic training ground for all social relationships, instilling in the individual appropriate moral and emotional reactions (Fan 2010: 15; Cline 2007: 367). The more a person learns to extend the virtue of ren to others beyond the family and the deeper she integrates them into her character, the more she develops a sound "sense of justice" (Cline 2007: 367). This in turn is what is needed to become a junzi 君子, a morally complete person, who also qualifies to become a state official, as the state in turn is imagined to function like a family at large.

These drastically truncated remarks about Confucian ethical thinking at large may help the reader understand why relationships, the ideal of harmony, the family and each person's moral development are central aspects of Confucian ethical arguments. CE moreover highlights the uniqueness of each person, the contextual peculiarities of each situation and the differing degrees of diligence and realized virtue in different people.

While searching for social justice in a Confucian context, we must recognize that there is no single concept in CE that integrates the various denotations that lie at the bottom of the classic Western notion of "justice," a fact prominently noted by many scholars (Hall and Ames 1987: 131; Peerenboom 1990: 17; T. Lee 1995: 125). Despite this lack and despite the fact that Confucian sensitivity to context may be at odds with abstract and generalizing justice considerations (Xiao 1997: 539), it is still true that the ancient CE texts discuss "concerns related to justice" and seek to create a "capacity for a sense of justice" that contemporary CE can draw on (Wong 2017; Cline 2007: 379). Here we can take note of but a few central Confucian concepts that express the kind of impartiality, reciprocity, and desire for social stability that are at the core of contemporary CE justice considerations. (1) $Y i$ 義 describes the internalized disposition to set things right. It aligns the right with the true as the "original, authentic, profound, and good substance of things" and "opposes the vice of excessive concern for profit" (X. Chen 2008: 30; Cline 2007: 369). (2) Shu 恕, literally “sameness of heart," denotes the empathetic understanding of another person's situation, especially when the person is hungry or in need. Empathy-filled perception prompts the self to help, even if the other cannot reciprocate (Li 2014: 139-141). (3) Gong 恭 denotes the kind of impartiality that is expected of state administrators in order to "treat all subjects without favoritism or prejudice" (Chan 2001). (4) Finally, ren connotes the obligation to strengthen relationships between people. Integrating empathy and the moral rationality of the Golden Rule with an emotional substructure of love and a commitment to care for others surpasses the framework most Western philosophers make use of when they talk about justice (Cline 2007: 368). ${ }^{6}$

Arranging these concepts in order to create a harmonious society, the Confucian picture of what is socially just stands out in a characteristic way: it does not merely consider issues of fairness and impartiality in distributing basic goods and liberties, but is also concerned with setting relationships right and growing "resources for building

\footnotetext{
${ }^{6}$ Such an integrated view may remind the Western reader of the coherence which Aristotle had in mind when he outlined the mutually conditioning relationship between general and special justice (Nicomachean Ethics, book V).
} 
mutual concerns and cooperative relationships between opposing parties" (Fan 2010: 13). According to Xunwu CHEN, "Normative justice [asks...] how in the distribution of these things each person is treated as a human being and as the end and how, accordingly, human values and bonds are promoted" (X. Chen 2008: 4). This of course exceeds by far the scope of abstract, depersonalized accounts of social justice. CE joins the process of cultivating a sense of justice as a virtue in the individual with the institutional procedures of finding and carrying out just judgments. In doing so it manages to keep these two "faces of justice" (Ci 2006: 7) close together: it joins motivational aspects of justice with institutional aspects of justice into one coherent whole. While Western philosophical deliberations about social justice say little about the first and keep silent about the interplay of the two, CE emphasizes their connections (Cline 2007: 379).

Poverty in a Confucian ethical understanding is a negative and alterable state of life causing pain and making it hard for human beings to live a moral life (Richter 2007: 2). CE considers material goods to be good and helpful for self-cultivation (Chan 2009: 266). Poverty then encumbers the capacity for moral behavior, because "as to the people, if they have not a certain livelihood, it follows that they will not have a fixed heart" (Mencius 1A7; Legge 2011: 147). Commenting on this famous quote, contemporary scholars emphasize that "poverty is conducive to negative emotions" (D. A. Bell 2006: 238), making "deference or other virtuous behaviour much more difficult" (Angle 2012: 134).

The causes of poverty are typically ascribed to governmental mismanagement. Drawing on the classics, CE holds that the "satisfaction of people's basic interests confers ultimate legitimacy" on governmental authorities (Bai 2012: 64; Mencius 1A7; Analects $16.1,20.1)$. Therefore "the very existence of poverty is $[\ldots]$ an imperative for those in authority to address it." If they do not manage to fight poverty successfully and restore the overall public well-being, their legitimacy is lost (Nosco 2010: 124).

The ethical reflection of poverty in CE yields three principled insights:

(1) Preventing poverty: CE summons those in governmental responsibility to care for the enrichment of all by securing their basic means of living as their first priority (Chan 2001; D. A. Bell and Chaibong 2003: 234; T. Lee 1995: 139). In addition, the government must provide basic education for all, as this is a prerequisite for sound moral development. A "just society must satisfy the moral and material needs of the common people" (T. Lee 1995: 132). Moreover, it must guarantee a distribution of resources that will prospectively enable every human person to lead a self-sufficient life. Here the ancient jingtian 井田 system to allot land evenly to all families in a village is often cited as a paradigmatic example (H. Chen 1911/ 2002: 531). Private property claims are subordinate to this primary government task (D. A. Bell 2006: 243).

(2) Accepting differences: Differences and income inequalities beyond the measure of basic sustenance are legitimate. In fact they are a necessary expression of harmony: to the degree that people differ in their "natural" capacities, their education, diligence or their moral refinement, $\mathrm{CE}$ considers corresponding income differences as merely reflecting differing contributions to the public welfare, that merit different rewards (Bai 2012: 70; Fan 2010: 18; Schilling 2010: 108; C. Lee 2009: 216). Meritocratic stratifications are counterbalanced, however, by the communal performance of rituals: regularly uniting people of all social backgrounds in a positive atmosphere for common ritual practice strengthens a sense of connectedness and mutual 
deference (Neville 2008: 94). This, in turn, strictly limits morally justifiable income differences (Bai 2012: 70; Angle 2012: 134).

(3) Providing for the poor: CE organizes welfare for the poor in a three-layered system (Chan 2009). First and foremost, there is the assistance of one's immediate family. If there is no family or the help needed exceeds the resources of the direct family, neighbors and friends are obliged to help the needy person. If their resources are also depleted, then CE summons the state to provide welfare assistance for the needy as a last resort (Peng 2008: 166). CE criticizes the Western welfare state system for providing help apart from familial or friendship relations. "If a son is able to provide care and help to his parents, it would be seriously wrong to shed his responsibility onto other people or the government" (Chan 2003: 243). CE believes that de-relationalizing poverty relief will pave the way for "grave moral, political and economic hazards" (Fan 2010: 74).

With regard to global justice and potential obligations to help the poor in faraway countries, CE shows two dialectical tendencies, of which the second appears somewhat more dominant. First, we see a cosmically inclusive quest for "universal harmony" (X. Chen 2008: 61). We notice the unlimited scope of the virtue of ren (Chan 2001: 67), and observe its "principalist-universalist conception" (Mittag 2010: 70). Furthermore, CE alludes to the perspective of tianxia 天下 as the proper moral point of view even-handedly making all people under the sky the principal objects of moral concern (Angle 2012: 78). Therefore, territorial boundaries do not have any principled moral significance. Consequently, the suffering of distanced people does matter (Chan 2001: 67), at least as a sign of cosmic disharmony. Hence Confucian scholars consider it their task to devise suitable political systems helpful for all people and nations under heaven (Bai 2012: 5; Zhao 2009: 6). Second, CE does not argue for a duty to equally care for all human beings in need. Its acceptance of asymmetrical relationships in family and state, as well as its sensitivity toward the particularities of each case and setting as well as its realistic appraisal of man's limited capacity to empathize with others, has established the important principle of "universal but unequal love" (Fan 2010: 19; Bai 2012: 35). Consequently, Western cosmopolitanism is taken to be too anonymous and "too idealistic, paying insufficient attention to humans' natural and justifiable sentiments. Instead of people loving everyone, cosmopolitanism may lead to them loving no one" (Bai 2012: 46).

\section{Poverty and Justice in a Christian Ethical Understanding}

Christian social ethics considers and critiques structures of social interaction in light of the coming kingdom of Christ. Its prophetic perspective typically transcends the confinements of nation state politics. Many Christian ethicists, especially those from a Catholic or Reformed theological background, summon Christians to take up responsibility for the development of a globalizing world (Paul VI 1967: 12-42; United States Catholic Bishops 1986: 363; Benedict XVI 2009: 9.42).

Poverty is viewed as a combination of material deprivation and social exclusion, that is: a lack of basic goods and isolation from others (Benedict XVI 2009: 53; Van Til 2007: 10). CSE considers godlessness to be the root cause of social isolation and hatred that leads to distrust and greed crowding out divinely bestowed capacities to love and 
care. The poverty of the poor then is taken to be a result of widespread godlessness. Being mindful of God's special concern for the poor (Pontifical Council 2006: 182) and the biblical-prophetical critique of greed as idolatry violating the demands of distributive justice (Schweiker 2004: 50), contemporary CSE locates the concrete origins of poverty in personal and institutionalized forms of greed and neglect.

As global justice considerations are complex and manifold in CSE, I present here only a few relevant aspects. For the sake of clarity, they are clustered around central CSE themes.

Personality: Considering all human beings as divinely dignified persons and believing in the material goodness of creation (Gaudium et Spes 69), CSE rejects dualistic devaluations of the body, highlights the physically restorative dimension of salvation (Wright 2008), and demands the universal recognition of the human right to an economic minimum for all (Gaudium et Spes 12; Van Til 2007: 107-112; Hicks 2000: 186). Furthermore, Christian thinking about persons is characterized by linking sociality with individuality (Benedict XVI 2009: 53-54). As communion and relationality are central to the Trinity and hence to human beings as imago, CSE champions a relational configuration of justice (Jackson 1992: 210-212), rejects solipsistic accounts, eschews libertarianism and, despite appreciating the universal scope of human rights, it is reserved against its individualistic facets.

CSE's conception of the person is also shaped by the awareness of sin. Lack of trust and pathological self-focus result in fears and fights and harm social relationships (Groody 2007: 11; John Paul II 1988: 36). By imposing measures of social justice, CSE seeks to counteract these dignity-degrading dynamics. Justice then carries two facets. On the one hand, it mirrors God's ongoing, gracious and effective power to restore relationships and communities, aligning it with trans-reciprocal grace (Moltmann 2012: 168-177). On the other hand, it "points to the tension between the ideal of Christian love and the harsh necessity of sustaining justice in a fallen world" (Porter 2005: 234).

Solidarity: In Christian thinking, solidarity is not just a "feeling of vague compassion [... but] a firm and persevering determination to commit oneself to the [...] good of all and of each individual" (John Paul II 1988: 38). Solidarity distributes the duties to help in a fair and acceptable manner and imposes these demands on both attitudes and structures. Viewing solidarity inspired actions as a matter of justice, while at the same time locating its motivational basis in the enabling context of divine love, reveals the Christian fusion of love and justice (Benedict XVI 2006: 6; Ci 2006: 166, 208-211).

A prominent characteristic of Christian solidarity is its universal scope calling for global solidarity (United States Catholic Bishops 1986: 258; cf. Cahill 2013). That call is alternatively (or jointly) anchored in a global common good (Cahill 2002), belief in the global human family (Benedict XVI 2009: 54; Van Til 2007: 140), which is a Christian affirmation of the common morality already embedded in international human rights norm or empirically in the increasing global interdependences (Walker 2008). The more particularistic strands of Christian thinking that emphasize the incompatibilities and "profound differences" between cultures and religions are yet hopeful that consensus about global matters of solidarity can be reached along the lines of "characteristically human needs and inclinations" (Porter 2001: 120-121).

Subsidiarity: This strikes a balance between communal and personal responsibilities (Paul XI 1931: 79). It summons the higher governing bodies to help smaller units by providing all necessary means to lead self-sufficient lives and it summons individuals and smaller groups to do all they can to ward off poverty (United States Catholic 
Bishops 1986: 71). Subsidiarity thus expresses a "relational anthropology that avoids both the opposite extremes of individualism and collectivism" (Curran 2002: 9). With regard to global poverty, subsidiarity emphasizes the local responsibility as well as the obligation of transnational institutions to coordinate help. It also requires a collective obligation to found such transnational institution (Gaudium et Spes 85).

Preferential Option for the Poor: This refocuses ethical attention back on a central biblical tenet, namely God's special concern for the poor and his call to liberate the oppressed (Boff and Pixley 1989). Starting ethical deliberations by looking at the poor has altered and refocused CSE's conception of social justice: beyond procedural fairness and mere distributional considerations, social justice inspired by the ]"preferential option" came to be spelled out as participation (United States Catholic Bishops 1986: 71; Bedford-Strohm 2008: 144-162). The disadvantaged must have the chance to participate in all central systems of cooperation, thereby "paving the way for new relations among people" (D. M. Bell 2004: 187). Justice as an inclusive push to enable participation follows the biblical vision of divine justice as a unifying force "effecting communion" (D. M. Bell 2004: 189) and champions the development of people's capabilities over the mere reward of individuals' performance, repositioning justice as "generous justice" within the divine order of charity (Forrester 2001: 204).

\section{Harmonious Resonances}

After considering the two traditions and their distinct ideas about poverty, justice, and global obligations, let us step back for a moment. Let us imagine the two traditions to be two distinct pieces of music. As we listen to both and hum along with their tunes, an impression remains: despite all differences and peculiarities, there seem to be keynotes in each composition that resonate well with similar elements in the other. These resonances appear to be the most natural starting points for dialogue.

As I engage the resonances, a methodological remark may be appropriate. Tracking resonances requires balance, as the road of comparative dialogue, which we build as we progress, slopes on two sides: looking at the similarities may blur our vision, especially when we lack a measure to judge their significance; looking at the differences, however, may lead us to viewing similarities as nothing but fake images, like two dimensional snap shots of moving objects, where a pyramid may look like a cube. I therefore suggest that we balance the resonances we encounter not by an analogue portrayal of differences, but rather by giving each tradition the chance to critically "blind-spot" the other, that is, to voice its own concerns about what it perceives to be flaws in the constructions of the other.

Both traditions affirm the bodily-material significance of human life. A minimum of resources is deemed to be necessary for human flourishing and hence morally required to be given to every human being. Lack thereof constitutes poverty and signifies immorality of societies wherein it occurs.

Both traditions furthermore view humans not as self-sufficient monads, but as beingsin-relations, and both traditions share the belief that social isolation is an important aspect of what causes poverty. Poverty then essentially results from a relational malfunction, namely a lack of empathy preventing people from building relationships of mutual benevolence. Both traditions consider stark income inequalities to be conducive to that kind of social isolation and alienation which in turn engenders poverty. 
Turning to the two traditions' conceptual accounts of social justice, we observe a fundamental concordance diverging significantly from liberal philosophical accounts of justice: any morally suitable principle of justice, both traditions agree, must be guided by the concern to establish a public order that champions other-regard and mutual benevolence, lest it infringes on the overarching goal of morality to connect people with each other. Hence both traditions are also likely to impose absolute limits on material inequalities. CE here accentuates the perfectionist duty of government to encourage other-regarding, harmonycreating actions which will lead to a narrowing of income gaps, while CSE advocates a paradigm of generous justice, which comes to terms with man's depravity, yet points society toward the generously reconciling power of divine justice (Huang 2015; D. M. Bell 2004: 187). Both traditions are quite explicit that, given the immaturity (CE) or depravity (CSE) of man, there is an intense need of strong moral resources that can grow and disseminate otherregard and benevolence in and between people, thus transcending self-interest and confined reciprocity considerations in order to create well-ordered, stable societies.

Their conceptual accounts of justice are furthermore characterized by a careful kind of alertness to the threats of poverty. Both traditions sketch out concepts of social justice that require their followers to ensure, first, that every human being has access to all basic material means for sustenance and personal development and, second, the protection and increase of relational harmony (CE) or participation (CSE). Both argue that these demands must not be separated from one another, as sustenance and development are essential for overall societal harmony or participation.

Assigning distinctive duties to help to the various levels of society, both traditions implement patterns of responsibility ascription that address the self-help capacities of each societal unit and only summon higher institutions to help when these capacities do not suffice. In doing so both traditions acknowledge the validity of property rights, while at the same time restricting these entitlements wherever the life and well-being of others is at stake.

With regard to global duties to help, both traditions share a universalist ethical perspective to a certain degree - they emphasize the equal initial dignity of all human beings. Neither considers national boundaries to have principle moral significance and both propose a global political order upheld and monitored by effective world governance institutions that ensure the longlasting eradication of world poverty.

\section{Differences and Blind Spots I: The Question of Moral Motivation}

Western political thought is cosmopolitanism, advocating universal and equal love. But [...] Confucians would say this is too idealistic, paying insufficient attentions to humans' natural and justifiable sentiments. Hence instead of people loving everyone, cosmopolitanism may lead them to love no one. Thus [with regard ...] to international relations the Confucian idea of universal, but hierarchical love [...] offers a realistic utopia for the global community. (Bai 2012: 46)

In this brief Confucian account of a "realistic utopia for the global community," Tongdong BAI describes the cross currents between the goals of universal love and care and the moral psychological confinements ("natural sentiments") that have led Confucians to limit the duty to help needy strangers. This kind of moral realism that Bai 
talks about deserves more attention as we seek to bring Confucian ethics in dialogue with Christian Social ethics, which — in many of its strands - is a strong advocate of universal solidarity.

Confucian ethicists insist that moral norms must be constructed in direct consonance and congruence with the available motivational resources. Proposals of new moral goals, such as extending social justice to the global sphere, must go hand in hand with a moral training agenda that is likely to expand people's moral sentiments correspondingly. As moral motivations are scarce goods, they must never be overburdened, lest the process of moral formation be hampered by frustration. Confucian awareness of the reach and limits of motivations ("realistic utopia") appears to be a vital contribution to a feasible account of global justice.

As noted above, however, $\mathrm{CE}$ insists that moral formation has been tied closely to family socialization, as family rituals and relationships are naturally best suited to integrate cognition, volition, and emotion in just the right way to create stable motivations for otherregarding considerations and actions. However, by linking moral formation and family life so closely, CE opts for a "care-with-gradation" principle: empathy-inspired obligations to care decline as relational distances grow. While in its ideal vision of social life Confucian ethics strongly affirms "universal benevolence" regardless of family relationships, since "all within the four seas are brothers" (Nylan 2001: 196-197), it demands that we set real human beings with their actual emotions and limited motivations at the starting point of all this-worldly ethic reflections. Confucius himself therefore considered filial love to be "the most natural stepping stone enabling human beings to expand their care outwards," and Mencius' remarks about ren (Mencius 1A7) make Confucian scholars defend a gradual expansion paradigm: "If one keeps extending one's care, eventually one will embrace everything in the universe" (Mencius $1 \mathrm{~A} 7){ }^{7}$ This extension, however, is a process that most ordinary men do not complete. Up till now Confucian ethicists have therefore been reluctant to ask the citizens of one country to help starving strangers in distant other countries (Angle 2012: 103). In fact, one can hardly "imagine circumstances under which Confucians would be exercised by poverty in alien lands" (Nosco 2010: 130).

Apparently, man's moral development in a lifetime is not fast enough to expand the kind of care social justice considerations invoke beyond the state. Many contemporary Confucian ethicists hence merely stipulate a (rather theoretical) duty of national governments to establish world governance structures, which - in the long run - must attain the power to dismiss morally evil national governments that greedily mismanage their own countries' economies for the sake of private profit (rent-seeking). This is the most CE demands, when asked what humans and/or societies ought to do in order to further global justice. Subsidiarity in CE appears to be less permeable as one moves upward through the layers of social organization.

As disappointing as this may be to cosmopolitan inclinations, the depth in which CE reflects the connection between moral norms and motivation is impressive and should be studied in more depth, even by devout cosmopolitans. Keeping in mind the subjectively limited moral care capacities and working to expand these motivations

\footnotetext{
${ }^{7}$ Cf. also Zhang Zai's 張載 words on the Western Inscription: "To be loving to the orphaned and the weak is the way to 'treat the young as the young should be treated.' [...] All in the world who are tired, infirm, crippled or sick; brotherless, childless, widows or widowers - they are all my siblings who are helpless and have no one else to appeal to" (cited in Bai 2012: 37).
} 
while painstakingly avoiding abrading them is a prudent strategy to deal with the scarce resources of moral motivation. Should global justice debaters not appreciate having found a voice that notoriously reminds them of the necessity to line up moral standards with moral motivations? Is this remembrance, the distinctly Confucian drive to consequently check every proposed ethical norm's motivational saturation, not exactly what global justice approaches need, in order to become robust (cf. Sen 2010: 45)? After all, it is that very chasm between normative demands and actual moral motivations that Western philosophers arguing about social and global justice seem to be quite worried about. Consider, for instance, Martha Nussbaum's remarks in Political Emotions concerning the need to develop, spread, and grow moral resources like empathy and agape in order to sustain our morally demanding social democratic order (cf. Nussbaum 2013). In A secular Age, Charles Taylor reminds his readers that the "very high demands of universal justice and benevolence" we assent to in the West need more powerful moral resources than we can currently tap (Taylor 2007: 397). "Concern for human beings on the other side of the globe whom we shall never meet or need" (Taylor 2007: 695) is simply too high a "demand of solidarity and benevolence" for modern societies that have "closed the transcendent windows" (Taylor 2007: 638).

How then will Confucian ethicists perceive Christian social ethics and its call to expand social justice considerations to the global sphere? After all, the Christian "gospel ethic of a universal solidarity" (Taylor 2007: 695) has historically been a driving force behind the moral aspirations that dominate today's global justice debate. Interestingly, $\mathrm{CE}$ does not question the universal justice standards nor the call for transnational solidarity advocated by CSE per se. What CE does question, however, is the motivational basis for these demands. If a tradition summons its adherents to show solidarity with distant strangers, it must, according to $\mathrm{CE}$ convictions, also render a realistic account of a motivational basis for such far-reaching demands.

Responding to this critical inquiry, CSE would most likely answer that the desire to implement just global structures essentially "arises from loving gratitude for the saving acts of God" (United States Catholic Bishops 1986: 39), to which CE would reply, that the exceptionally high moral demands of CSE only matches its motivational basis, if that thankfulness has been effectively ingrained in all people who find themselves morally addressed by the demand. If CSE's moral demands are tangled up so closely with the Christian belief in, and experience of the graciously restorative divine justice, then that link must be transparent and constantly alluded to. It would be careless to expect people who do not possess these moral resources to conform to such kind of universal solidarity morality.

CE would encourage CSE to be clear about its motivational premises. It would exhort CSE to confess that its moral demands are accessible only to those who have experienced repentance, reconciliation, and incorporation into what Christians describe as the divinely established community. CSE and CE might then start to discuss whether this transformative experience is in fact a precondition for every moral actor finding himself addressed by the responsibilities and duties of a CSE-like vision of global solidarity, or whether it is sufficient if the rules and institutions relevant to issues of global justice might be devised or governed by junzi-like people, who have personally experienced the abovementioned transformation.

It is not unreasonable to imagine that, throughout the course of discussion, CSE will recognize the value and validity of the Confucian critique and seek ways to keep its moral demands and motivations linked more closely together. That may lead it to (a) 
make the community of the redeemed a stronger focal point of its ethical reflections, as Stanley Hauerwas has, for instance, demanded for the last decades; (b) reduce its aspired norms regarding global justice, recognizing that post-Christian societies in the West and post-Confucian societies in the East are both similar in their exclusively humanist moral outlook and hence do not provide people with morally motivating resources to join benevolence and justice as closely together as genuine Christian beliefs demand; or (c) not lower its standards, but become more critically prophetic, not expecting to actually influence the course of political decisions pertaining to global justice directly.

As we now turn the perspective of critical scrutiny the other way around, let us also engage the Christian social ethical potential to blind-spot the Confucian account: CSE would certainly question CE's omission to make poor strangers a central point of its moral agenda. In doing so it would focus on the Confucian construction of virtue, love, and care exclusively from within family socialization. While CSE also values family virtues, its concern to expand generous solidarity beyond the fringes of already existing communities transcends the gradual growth paradigm Confucius and Mencius suggest, as well as their "care-with-gradation-principle." In CSE, nonexpectant acts of giving, caring, and sharing must precede, underlie, inspire, and motivate any stable social system, as justice is seen to depend on some kind of "original generosity" counteracting the dynamics of original sin manifesting itself as scarcity of benevolence (Shen 2007: 181; Benedict XVI 2006: 6; Forrester 2001: 204). Confucians might respond by pointing out that parental love in fact is a form of such original generosity. CSE may agree but explain its critique in yet another way: because of the Christian conviction that man's ability to empathize with others is so deeply marred by sin, CSE considers all ethical approaches that put in-group focused sentiments at the start of moral formation processes to be too prone to become content with harmony within a certain group, thereby leaning toward exclusivist behavior at its outside fringes. Put another way: CSE describes benevolence as originating apart from man in the loving kindness of God, which works its way into human hearts thereby transforming moral outlooks, while CE describes benevolence as the result of virtue education and moral self-cultivation which permeates outward into social institutions. Therefore, justice as a personal virtue and justice as an institutional virtue are closely tied together in CE. In CSE there may be a stronger hope that state officials will be able to implement and enforce socially just structures by law which work to the benefit of all, even when the state of virtue in many people does not fully correspond to these structures and laws. ${ }^{8}$

\section{Differences and Blind Spots II: Causes of Poverty and Strategies of Poverty Relief}

In a Confucian conception, poverty may either be self-inflicted or result from the failure of government to perform its duties (cf. above), or simply signify general moral decay. Third party fault or negligence finds little explicit consideration. The systemic responsibilities of intermediate actors such as companies competing globally for cheap labor

\footnotetext{
${ }^{8}$ To the Confucian charge that such an approach is legalist in its nature and abandons the desire for individuals to virtuously cultivate themselves, CSE might answer by pointing to the integrated view of the law in Christian reflections as expressed, for instance, in Dietrich Bonhoeffer's discussion of the three usus legis (cf. Bonhoeffer 1949: 248).
} 
are not a primary concern. While CE does emphasize governmental responsibility to regulate the national economy so as not to inflict more harm on the disadvantaged, there is little reflection about supranational governing responsibilities to regulate trade and commerce so as to not harm the global poor. CSE would consider the Confucian poverty analysis to stand in danger of overlooking these connections. It would also suggest that describing poverty as self-inflicted is dangerous, as "blaming the poor" for their poverty typically signifies a lack of sound analysis (United States Catholic Bishops 1986: 197).

With regard to poverty relief, CE tends to assign the poor a greater responsibility to work their way out of poverty. Its insistence that governments are responsible to ensure every person an equal chance to earn a basic income (cf. above) does not lead CE to postulate a direct state responsibility for poverty relief (Peng 2008: 166). Governments "rather must provide the conditions in which people can make a living, so that they can help their families and relatives if they are in need" (Chan 2003: 238). The direct responsibility to help lies with the needy person himself and - in consecutive levelswith his family members, as well as with his friends and neighbors (Chan 2003: 244). However, CE does not spell out what the poor can do if family, friends, and neighbors do not discharge their duties. The poor then may well suffer from the immorality of others without having the chance of appeal.

CSE would mark such "indeterminacy of benevolence" (Chan 2003: 244) as a problematic blind spot and insist that sustenance is so essential that its fulfilment cannot be made dependent on the state of virtue of family members, friends, and neighbors. It therefore demands government-led systems of poverty relief. In its argument CSE might state that it shares — at least in some of its strands - the "moderate perfectionist vision" of CE making it the "government's job to promote individuals' benevolent actions toward others" (Huang 2015: 181). Yet CSE would insist that there has to be a way to prevent the poor from suffering the consequences of others failing to duly develop their virtues. In reply Confucians might point to what they consider a blind spot in CSE: does the separation of care from face-to-face relationships not also cut off poverty relief from natural sentiments of benevolence and empathy? Do anonymous welfare systems not become susceptible to misuse and fraud, while motivations to help deteriorate as they are no longer sustained by ritualized personal encounters between the needy and the helper (cf. Fan 2010: 74)?

At this point it is not hard to imagine that concrete-universal dialogue may in fact lead to mutual learning: Christian social ethical critique may inspire Confucian thinkers to pay more attention to a clear kind of bottom-up subsidiarity, integrating formalized lines of appeal to help those whose families and neighbors do not help sufficiently. CSE in turn should be inspired by the Confucian insistence that poverty relief ought to be embedded in direct local context and responsibility structures, wherever possible. Bringing personalized care and formalized justice considerations closer together is, after all, characteristic of a biblical vision of justice.

A gradual difference between regard to grace and merit-considerations is likely to remain, however: while CSE in its consciousness of ultimate human dependence on divine grace leads toward institutionalizing elements of grace into the social structures of society (see above), CE is convinced that a harmonious configuration of society must be guided by a perspective of justice that arises from counting and comparing people's different merits (Chan 2009: 265). Hence CSE will be more likely to postulate a moral 
duty to help the worst-off no matter what the circumstances of their becoming poor may have been, while CE may be more likely to filter the deserving from the non-deserving poor, providing help more freely to those who are more willing to cooperate and work toward improving the circumstances of their lives. This difference, however, could well be accounted for by providing conceptual space for different localized implementations of a universal standard of justice to fight poverty. A commonly agreed upon framework of global justice can leave room for culturally diverse social welfare systems.

\section{Conclusion}

In conclusion, we are now able to delineate significant commonalities (paragraphs 1 and 6) and potential complements (paragraphs 2 to 4) between CSE and CE with regard to global justice considerations. We are also able to contrast this account and sharpen its contours by delineating the contradictory features of the two traditions (paragraph 5) that emerged in the discussion.

(1) Affirming the bodily-material significance of human life and the moral significance of a material minimum as well as sharing the diagnosis that poverty results from a moral failure, namely lack of other-regard signifying relational breaches, are remarkable commonalities. Moreover, the joint demand on government to address the problem of people living in poverty and the moral authorization of governing bodies to curb property entitlements for purposes of redistribution are similar in both traditions. The most notable element of a common moral ground seems to be the consistent push to consider distributive matters in close conjunction with relational matters throughout all moral considerations.

(2) Turning to complementary aspects, our discussion leaves us with the impression that CSE will have reason to appreciate the Confucian reminder to keep moral demands and moral motivation more closely aligned: CSE must give a clearer account about what will actually make people abide by its stipulated norms of universal solidarity - may it be an intense process of moral learning and/or a personally transforming experience of divine generosity. In fact, CSE may be brought to admit that many of its recent contributions have not sufficiently spelled out the moral resources it preconceives.

(3) With regard to analyzing the reasons behind poverty, the kind of concreteuniversal debate envisioned in this article may bring CE to pay closer attention to intermediate actors, their causal role in engendering poverty, and the consequent outcome liability falling on them. Confucian ethicists may also be brought to apply the tool of outcome liability analysis to the moral reflection of international trade treaties. After all, Confucian scholars are quite outspoken about the need to regulate economic interactions to the benefit of all parties involved.

(4) The concrete universal dialog also brings to the forefront an interesting dialectical tension with regard to poverty relief: CE reminded us of the dangers of anonymizing relief, namely the danger of misuse on the side of the recipient and the danger of decreased motivation to give on the side of the giver. CSE in turn highlights the dangers of assigning relief obligations to family and friends without establishing formalized ways of appeal for those whose relatives and 
friends refuse to help. While tradition-specific differences will persist, chances to learn from this exercise in mutual blind-spotting are obvious: CE may accept a higher degree of a bottom-up permeability in its subsidiarity relief system and CSE may rediscover the importance of person-to-person encounters for the motivational underpinnings of its relief systems, ideally leading to an increase in the society-wide willingness to care for others.

(5) Principle differences remain between the "love-with-gradation" principle and the ethic of a universal solidarity, as the scope of what must morally concern every person is judged differently. CE upholds that it is not morally sound to expect people who have not been trained in virtue at home to be concerned about distant needy strangers. Cosmopolitanism will not be the right label for a common global justice ethic. Even "rooted cosmopolitanism" may not fit, as Confucian thinkers will never agree to sign a treaty that promises universal concern for all who suffer without adequate moral resources to cash in that promise.

(6) Finally, it must be noted that both traditions do support the construction of transnational governance structures. While CSE proclaims this loudly, as transnational governance networks appear to be a good tool to translate its universal solidarity claims into political practice, CE does also support the installation and empowerment of transnational governance institutions (cf. above), even though it is more reserved about their tasks. However, even the Confucian job description for such institutions, namely to dismiss those governments that principally exploit their own societies, may be a gigantic step forward in the struggle to effectively fight world poverty.

Note that these results will only unfold into their full potential as a viable contribution to the ethical discussion of global justice as more and more traditions are included into this concrete universal-debate and as the results of these concrete intercultural discussions are tied back to the more abstract-universal debate about global justice. This however, for now, remains as a future task and challenge (cf. Metz and D. A. Bell 2012, Rauhut 2017).

Funding Information Open Access funding provided by Projekt DEAL.

Open Access This article is licensed under a Creative Commons Attribution 4.0 International License, which permits use, sharing, adaptation, distribution and reproduction in any medium or format, as long as you give appropriate credit to the original author(s) and the source, provide a link to the Creative Commons licence, and indicate if changes were made. The images or other third party material in this article are included in the article's Creative Commons licence, unless indicated otherwise in a credit line to the material. If material is not included in the article's Creative Commons licence and your intended use is not permitted by statutory regulation or exceeds the permitted use, you will need to obtain permission directly from the copyright holder. To view a copy of this licence, visit http://creativecommons.org/licenses/by/4.0/.

\section{References}

Amin, Samir. 1974. "Accumulation and Development." Review of African Political Economy 1.1: 9-26.

Angle, Stephen C. 2012. Contemporary Confucian Political Philosophy. Cambridge: Polity Press.

Bai, Tongdong. 2012. China: The Political Philosophy of the Middle Kingdom. London: Zed Books. 
Bedford-Strohm, Heinrich. 2008. "Poverty and Public Theology: Advocacy of the Church in Pluralistic Society." International Journal of Public Theology 2.2: 144-162.

Beitz, Charles R. 1983. "Cosmopolitan Ideals and National Sentiment.” The Journal of Philosophy 80.1: 591600 .

Bell, Daniel A. 2006. Beyond Liberal Democracy: Political Thinking for an East Asian Context. Princeton: Princeton University Press.

Bell, Daniel A., and Hahm Chaibong. 2003. Confucianism for the Modern World. Cambridge: Cambridge University Press.

Bell, Daniel M., Jr. 2004. "Deliberating: Justice and Liberation.” In The Blackwell Companion to Christian Ethics, edited by Stanley Hauerwas and Samuel Wells. Malden: Blackwell.

Benedict XVI. 2006. Deus caritas Est: God is Love. Encyclical Letter. Vatican: Libreria Editrice Vaticana. 2009. Caritas in Veritate: Charity in Truth. Encyclical Letter. Washington, D.C.: Office of Publishing and Promotion Services, United States Catholic Conference.

Benhabib, Seyla. 1986. Critique, Norm, and Utopia. New York: Columbia University Press.

2013. Situating the Self: Gender, Community and Postmodernism in Contemporary Ethics. Cambridge and Malden: Polity Press.

Berger, Peter L. 1988. “An East Asian Development Model?” In In Search of an East Asian Development Model, edited by Peter L. Berger. New Brunswick: Transaction Publ.

Boff, Clodovis, and Jorge V. Pixley. 1989. The Bible, the Church, and the Poor. Maryknoll, NY: Orbis Books.

Bonhoeffer, Dietrich. 1949. Ethik. München: Chr. Kaiser.

Cahill, Lisa Sowle. 2002. "Toward Global Ethics." Theological Studies 63: 324-344. 2013. Global Justice, Christology and Christian Ethics. Cambridge: Cambridge University Press.

Chan, Joseph. 2001. "Making Sense of Confucian Justice." Forum for Intercultural Philosophy 3. http://them. polylog.org/3/fcj-en.htm (last accessed on November 1, 2019).

2003. "Giving Priority to the Worst Off: A Confucian Perspective on Social Welfare." In Confucianism for the Modern World, edited by Daniel A. Bell. Cambridge: Cambridge University Press. 2009. "Is there a Confucian Perspective on Social Justice?" In Western Political Thought in Dialogue with Asia, edited by Cary J. Nederman and Takashi Shōgimen. Lanham: Lexington Books.

Chen, Huang-Chang. 1911/2002. The Economic Principles of Confucius and His School, vol II. Bristol: Thoemmes.

Chen, Weigang. 2014. Confucian Marxism: A Reflection on Religion and Global Justice. Leiden: Brill.

Chen, Xunwu. 2008. Justice, Humanity, and Social Toleration. Lanham: Lexington Books.

Ci, Jiwei. 2006. The Two Faces of Justice. Cambridge, MA: Harvard University Press.

Cline, Erin M. 2007. "Two Senses of Justice: Confucianism, Rawls, and Comparative Political Philosophy." Dao: A Journal of Comparative Philosophy 6.4: 361-381.

Curran, Charles E. 2002. Catholic Social Teaching: 1891-Present. Washington, D.C.: Georgetown University Press.

De Soto, Hernando. 2001. The Mystery of Capital: Why Capitalism Triumphs in the West and Fails Everywhere Else. London: Black Swan.

Delanty, Gerard. 1997. "Habermas and Occidental Rationalism.” Sociological Theory 15.1: 30-59.

Fan, Ruiping. 2010. Reconstructionist Confucianism: Rethinking Morality after the West. Dordrecht: Springer.

Forrester, Duncan B. 2001. "Social Justice and Welfare." In The Cambridge Companion to Christian Ethics, edited by Robin Gill. Cambridge: Cambridge University Press.

Gaudium et Spes: Pastoral Constitution on the Church. 1966. Boston: St. Paul Editions.

Groody, Daniel G. 2007. Globalization, Spirituality, and Justice: Navigating a Path to Peace. Maryknoll, NY: Orbis Books.

Hall, David L., and Roger T. Ames. 1987. Thinking through Confucius. Albany: State University of New York Press.

Hellsten, Sirkku K. 2015. "Ethics: Universal or Global? The Trends in Studies of Ethics in the Context of Globalization.” Journal of Global Ethics 11.1: 80-89.

Hicks, Douglas A. 2000. Inequality and Christian Ethics. Cambridge: Cambridge University Press.

Hoogvelt, Ankie M. 2001. Globalization and the Postcolonial World: The New Political Economy of Development. Baltimore: Johns Hopkins University Press.

$\mathrm{Hu}$, Biliang. 2007. Informal Institutions and Rural Development in China. London and New York: Routledge. Huang, Yong. 2015. "Confucianism and the Perfectionist Critique of the Liberal Neutrality: A Neglected Dimension.” Journal of Value Inquiry 49: 181-204.

Jackson, Timothy P. 1992. "Christian Love and Political Violence." In The Love Commandments: Essays in Christian Ethics and Moral Philosophy, edited by Edmund N. Santurri and William Werpehowski. Washington, D.C.: Georgetown University Press. 
John Paul II. 1988. Sollicitudo rei socialis: Encyclical Letter. Washington, D.C.: Office of Publishing and Promotion Services, United States Catholic Conference.

Lee, Ching Kwan. 2009. "From Inequality to Inequity: Popular Conceptions of Social (In)justice in Beijing." In Creating Wealth and Poverty in Postsocialist China, edited by Deborah S. Davis and Feng Wang. Stanford: Stanford University Press.

Lee, Thomas C. 1995. "The Idea of Social Justice in Ancient China." In Social Justice in the Ancient World, edited by K. D. Irani and Morris Silver. Portsmouth: Greenwood Press.

Legge, James, trans. 2011. The Works of Mencius. Reprint. New York: Dover Publications.

Li, Chenyang. 2008. "The Philosophy of Harmony in Classical Confucianism." Philosophy Compass 3.3: 401-572.

2014. The Confucian Philosophy of Harmony. New York: Routledge.

MacIntyre, Alasdair. 1984. Is Patriotism a Virtue? (The Lindley Lecture at the University of Kansa). Lawrence: Kansas University Press.

Metz, Thaddeus, and Daniel A. Bell. 2012. "Confucianism and Ubuntu: Reflections on a Dialogue between Chinese and African Traditions." Journal of Chinese Philosophy 38 (suppl.): 78-95.

Miller, David. 2007. National Responsibility and Global Justice. Oxford: Oxford University Press.

Mittag, Achim. 2010. "Reconsidering Ren as a Basic Concept of Chinese Humanism." In Traces of Humanism in China: Tradition and Modernity, edited by Carmen Meinert. Bielefeld: Transcript.

Moltmann, Jürgen. 2012. Ethics of Hope. Minneapolis: Fortress Press.

Naím, Moíses. 2000. "Fads and Fashion in Economic Reforms: Washington Consensus or Washington Confusion?" Third World Quarterly 21.3: 502-528.

Neville, Robert Cummings. 2008. Ritual and Deference. Albany: State University of New York Press.

Nosco, Peter. 2010. "Confucian Perspectives on Poverty and Morality." In Poverty and Morality: Religious and Secular Perspectives, edited by Peter H. Hoffenberg and William Arthur Galston. Cambridge: Cambridge University Press.

Nussbaum, Martha. 2007. Frontiers of Justice: Disability, Nationality, Species Membership. Cambridge: Belknap.

2013. Political Emotions: Why Love Matters for Justice. Cambridge: Belknap.

Nylan, Michael. 2001. The Five "Confucian" Classics. New Haven: Yale University Press.

Okeja, Uchenna B. 2013. Normative Justification of a Global Ethic: A Perspective from African Philosophy. Lenham: Lexington.

Oruka, Henry Odera. 1981. "Rawls' Ideological Affinity and Justice as Egalitarian Fairness." In Justice, Social, and Global, edited by L. Ericson. Stockholm: Gotab.

1988. "The Philosophy of Foreign Aid: A Question of the Right to a Human Minimum." Praxis International 4: 465-475.

Paul VI. 1967. Populorum Progressio: On the Development of Peoples. Encyclical Letter. Washington, D.C.: Office of Publishing and Promotion Services, United States Catholic Conference.

Paul XI. 1931. Quadragesimo Anno. Encyclical Letter. New York: Paulist Press.

Peerenboom, R. P. 1990. "Confucian Justice: Achieving a Humane Society." International Philosophical Quarterly 30.1: 17-32.

Peng, Ito. 2008. "Welfare Policy Reforms in Japan and Korea: Cultural and Institutional Factors." In Culture and Welfare State: Values and Social Policy in Comparative Perspective, edited by Birgit Pfau-Effinger, Michael Opielka, and Wim van Oorschot. Cheltenham: Edward Elgar.

Pogge, Thomas W. 2010. World Poverty and Human Rights: Cosmopolitan Responsibilities and Reforms. Cambridge: Polity Press.

Pontifical Council for Justice and Peace. 2006. Compendium of the Social Doctrine of the Church. London: Bloomsbury.

Porter, Jean. 2001. "The Search for a Global Ethic.” Theological Studies 62: 105-121.

2005. "Trajectories in Christian Ethics." In The Blackwell Companion to Religious Ethics, edited by William Schweiker. Malden: Blackwell.

Rauhut, Andreas. 2017. "Expanding Motivations for Global Justice: A Dialogue between Public Christian Social Ethics and Ubuntu Ethics as Afro-Communitarianism." Journal of Global Ethics 13.2: 138-156.

Ravallion, Martin, and Shaohua Chen. 2007. "China's (Uneven) Progress against Poverty." Journal of Development Economics 82: 1-42.

Rawls, John. 1996. Political Liberalism. Columbia: University Press. 2001. The Law of Peoples. Cambridge, MA: Harvard University Press.

Rawski, Thomas G. 2011. "Is China's Development Success Transferable?" In Reform and Development in China: What Can China Offer the Developing World?, edited by Ho-Mou Wu and Yang YAo. London: Routledge. 
Richter, Antje. 2007. "Die Wahrnehmung von Armut im Alten China." In China und die Wahrnehmung der Welt, edited by Antje Richter and Helmolt Vittinghoff. Wiesbaden: Harrassowitz.

Schilling, Dennis. 2010. "Human Equality in Modern Chinese Political Thought." In Traces of Humanism in China: Tradition and Modernity, edited by Carmen Meinert. Bielefeld: Transcript.

Schweiker, William. 2004. Theological Ethics and Global Dynamics: In the Time of Many Worlds. Malden: Blackwell.

Sen, Amartya. 2010. The Idea of Justice. London: Penguin.

Shen, Vincent. 2007. "Globalization, Christianity and Confucianism: On Strangification and Generosity to the Other." In Dialogues of Philosophies, Religions and Civilizations in the Era of Globalization, edited by Zнао Dunhua. Washington, D.C.: Council for Research in Values and Philosophy.

So, Alvin Y. 2012. "Development Model." In Handbook of Contemporary China, edited by William S. Tay and Alvin Y. So. Singapore: World Scientific.

Taylor, Charles. 2007. A Secular Age. Cambridge, MA: Belknap.

United Nations. 2015. "The Millennium Development Goals Report.” New York: United Nations.

United States Catholic Bishops. 1986. Economic Justice for All: Pastoral Letter on Catholic Social Teaching and the U.S. Economy. Washington, D.C.: United States Conference of Catholic Bishops.

Van Til, Kent A. 2007. Less Than Two Dollars a Day: A Christian View of World Poverty and the Free Market. Grand Rapids: Eerdman.

Walker, Thomas M. 2008. "Who Is My Neighbour: An Invitation to See the World through Different Eyes." In Global Neighbors: Christian Faith and Moral Obligation in Today's Economy, edited by Douglas A. Hicks and Mark R. Valeri. Grand Rapids: William B. Eerdmans.

Walzer, Michael. 1983. Spheres of Justice. A Defense of Pluralism and Equality. New York: Basic. . 2010. "Afterword." In Poverty and Morality: Religious and Secular Perspectives, edited by William A. Galston and Peter H. Hoffenberg. Cambridge and New York: Cambridge University Press.

Wiredu, Kwasi. 1996. Cultural Universals and Particulars: An African Perspective. Bloomington: Indiana University Press.

Wong, David. 2013. "Chinese Ethics.” In The Stanford Encyclopedia of Philosophy, edited by Edward N. Zalta. https://plato.stanford.edu/archives/spr2013/entries/ethics-chinese/ (last accessed on October 23, 2019).

. 2017. “Comparative Philosophy: Chinese and Western.” In The Stanford Encyclopedia of Philosophy, edited by Edward N. Zalta. https://plato.stanford.edu/archives/spr2017/entries/comparphil-chiwes/ (last accessed on October 23, 2019).

Wright, N. T. 2008. Surprised by Hope. New York: HarperOne.

Xiao, Yang. 1997. "Trying to Do Justice to the Concept of Justice in Confucian Ethics." Journal of Chinese Philosophy 24: 521-551.

Zhao, Tingyang. 2009. "A Political World Philosophy in terms of All-Under-Heaven (Tian-xia)." Diogenes 56.5: 5-18.

Publisher's Note Springer Nature remains neutral with regard to jurisdictional claims in published maps and institutional affiliations. 